\title{
Medical Characteristics of Arid-Semi Arid Truffle (Terfezia and Picoa) in the Elazığ-Malatya region of Turkey
}

\author{
Türkiye'nin Elazığ-Malatya Çevresindeki Kurak-Yarı Kurak \\ Trüflerin Tıbbi Özellikleri
}

\author{
Research Article
}

Mehmet Akyüzi", Sevda Kırbağ², Burak Bircan²

'Department of Biology, Faculty of Science and Arts, Bitlis Eren University, Bitlis-Turkey.

${ }^{2}$ Department of Biology, Faculty of Science, Fırat University, Elazığ-Turkey.

\section{A B S T R AC T}

\begin{abstract}
n this study, the antimicrobial and antioxidant activity of Terfezia boudieri, T. claveryi, T. olbiensis, Picoa lefebvrei and $P$. juniperi were investigated. It was determined that the methyl alcohol extraction of $T$. boudieri, T. claveryi, T. olbiensis, P. lefebvrei and $P$. juniperi inhibit the development of $E$. coli, $B$. subtilis, $P$. aeruginosa, S. aureus, S. mutans, P. vulgaris, S. typhi, C. tropicalis and Trichophyton sp. at various levels (8 $\mathrm{mm}$ to $22 \mathrm{~mm}$ diameter) and their effect to remove the DPPH radical was more efficient at groups to which samples of $25 \mu \mathrm{L}$ (1.22\% to $2.58 \%), 50 \mu \mathrm{L}(2.31 \%$ to $3.28 \%)$ and $100 \mu \mathrm{L}(5.24 \%$ to $8.00 \%)$ were added. It was determined that methyl alcohol that was extracted from Terfezia species were more effective than Picoa species against test microorganisms. When the groups were compared in terms of concentration, the highest level of free radical scavenging effect at the group, to which we added a $100 \mu \mathrm{L}$ sample, was seen at T. boudieri with $8.00 \%$.
\end{abstract}

\section{Key Words}

Antimicrobial activity, antioxidant property, arid-semi arid truffle, edible mushroom, Terfezia, Picoa.

\section{ÖZET}

$\mathbf{Q}$ u çalışmada, Terfezia boudieri, T. claveryi, T. olbiensis, Picoa lefebvrei ve P. juniperi'nin antimikrobiyal ve Bantioksidant özellikleri araştırıldı. T. boudieri, T. claveryi, T. olbiensis, P. lefebvrei ve P. juniperi'nin meti alkol özütlerinin; E. coli, B. subtilis, P. aeruginosa, S. aureus, S. mutans, P. vulgaris, S. typhi, C. tropicalis ve Trichophyton sp.'nin gelişmelerini değişik oranlarda (8-22 mm çap) inhibe ettiği ve DPPH radikalini giderme etkisinin ise $25 \mu \mathrm{L}$ (\% 1.22-2.58), $50 \mu \mathrm{L}$ (\% 2.31-3.28) ve $100 \mu \mathrm{L}$ (\% 5.24-8.00) örnek eklenen gruplarda daha etkili olduğu tespit edilmiştir. Terfezia türlerinden elde edilen metil alkol özütlerinin, test mikroorganizmalarına karşı Picoa türlerinden daha etkili olduğu tespit edilmiştir. Derişime bağlı olarak gruplar karşılaştırıldığında ise $100 \mu \mathrm{L}$ örnek eklediğimiz grupta en fazla serbest radikal giderme etkisi \% 8.00 ile T. boudieri'de görülmektedir.

\section{Anahtar Kelimeler}

Antimikrobiyal aktivite, antioksidant özellik, kurak-yarı kurak trüfler, yenen mantar, Terfezia, Picoa.

Article History: Received: Oct 28, 2015; Revised: Nov 14, 2015; Accepted: Nov 28, 2015; Available Online: Dec $30,2015$.

Dol: $10.15671 /$ HJBC.20154315989

Correspondence to: M. Akyüz, Department of Biology, Faculty of Science and Arts, Bitlis Eren University, Bitlis, Turkey. 


\section{INTRODUCTION}

Trust hroughout human history, fungi have been used for nourishment, as functional foods to maintain good health and prevent ailments, and as a source of medicine to treat diseases [1-3]. Desert truffles have been found so far in most of the geographical areas characterized by these climate types, although historically, some of them have received more attention than other mushrooms. In some of these areas, hypogeous fungal species adapted to dry environments (steppes, deserts) are popularly known as desert truffles [4-6].

Desert truffles are hypogeous Ascomycetes that grow in arid and semiarid areas on every continent other than Antarctica (7). The desert truffles with the longest recorded history of use are species of Terfezia, Picoa and Tirmania, which are popular mainly in the Middle East, Mediterranean basin, and Northern Africa [6-8]. These desert truffles form mycorrhizas on the roots of plants in the Cistaceae family [7].

Desert truffles have been shown to provide a rich source of fiber, protein, amino acids, fatty acids, minerals, vitamins, and carbohydrates and to contain considerably higher values of fat, potassium, and phosphate than many commonly consumed vegetables [9-14]. Terfezia and Picoa are two of the most common edible desert truffles in the world. These fungi constitute a popular food and are particularly appreciated for their flavour and texture profiles in countries of the Mediterranean Basin as a whole [13]. Desert truffles are traditionally gathered not just for nourishment, but also for their curative and aphrodisiac properties [15-16]. The juice of desert truffles, mainly of T. nivea, T. claveryi, and T. boudieri, has been used in the Middle East to treat eye and skin diseases [16-17]. More recently food scientists have focused on the bioactivities of truffles, including their antioxidant, antiviral, anticancer, antimicrobial, hepatoprotective, antimutagenic and antiinflammatory activities $[9,12,18-27]$. They have been popular as functional foods in traditional medicine have been found to contain substances with powerful antioxidant activities, including ascorbic acid, anthocyanins, esterified phenols, free phenolics, flavonoids, and carotenoids $[9,12,17]$.
In this study, T. boudieri, T. claveryi, T. olbiensis, $P$. lefebvrei and $P$. juniperi are observed, which are well known and consumed in Elazığ-Malatya province of Turkey, and sold at the local bazaars. Villagers at rural areas pointed out that they consume these truffle types that they collect as daily source of nutrition, but they sell most of them to Malatya through merchants. It was also pointed out that the seasonal yield may not be high every year because of the unsuitable climatic conditions. It was observed that $T$. boudieri is the only product that has an economic value as it brings profit. P. lefebvrei, T. olbiensis and P. juniperi, which are used for daily consumption and are more popular amongs to the locals, don't have an economic value, as the first one is too small, the second one degrades quickly, and the third one can be found rarely and is very hard. It was observed that $T$. claveryi can be rarely found in the area and can be confused with T. boudieri by the local people.

Truffle types can grow in varios exclusive habitats depending on the region's climate, altitude, vegetation and soil structure. Little is known about the truffle in Turkey [28], as truffle fungi have received less attention than epigeous fungi. Turkey is rich in mushroom diversity, as well as medicinal plants. Turkish people have a tradition of using various types of mushrooms for food, instead of using them for the treatment of infectious diseases and various ailments. Therefore, it is necessary to know the levels of antimicrobial and antioxidant activities in truffles before using them. The purpose of this study was to evaluate the potential antimicrobial and antioxidant activities of arid-semi arid truffles in

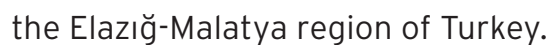

\section{MATERIAL AND METHOD}

\section{Truffle materials}

A wild samples of fresh Picoa lefebvrei (Pat.) Maire, Picoa juniperi Vittad., Terfezia boudieri Chatin, Terfezia claveryi Chatin and Terfezia olbiensis Tul. \& C. Tul. were collected from Malatya (Central, Kale, Battalgazi, Arguvan Districts and theirs vicinity) and Elazığ (Baskil district and its vicinity), Turkey (N $38^{\circ} 19^{\prime}-43^{\prime}$ E $038^{\circ} 19^{\prime}-51^{\prime}$ ' with an altitude of 690-1375 m, the beginning of March 
to the end of May (rarely continue until mid-July). They are usually collected near Helianthemum salicifolium (L.) Mill. and rarely H. ledifolium (L.) Mill. We identified the location of the truffles from crevices that appeared in the surface of the soil above the truffle. The samples were dried at room temperature for 15 days then placed in locked bags and stored at $25^{\circ} \mathrm{C}$ in lab. These samples were used in this study.

\section{Extraction procedure}

The dried and powdered mushroom materials were dried at $55^{\circ} \mathrm{C}$ in the oven for $1 \mathrm{~h}$. Then, 1 of these powdered materials were mixed with $10 \mathrm{~mL}$ it methyl alcohol solvent in a beaker and then placed on a rotary shaker for $24 \mathrm{~h}$. The aqueous solutions were then filtered using Whatman filter paper and then concentrated in vacuo for $15 \mathrm{~min}$ at $37^{\circ} \mathrm{C}$ using a Rotary evaporator. The concentration was then dissolved in $15 \mathrm{~min}$ of dimethylsulfoxide and stored at $4^{\circ} \mathrm{C}$ for further study. Then, $100 \mu \mathrm{L}(100 \mu \mathrm{g})$ extracts were injected into an antibiotic disc (Antimicrobial supsestibility test disc, Oxoid) having a diameter of $6 \mathrm{~mm}$ (29).

\section{Test microorganisms}

A total of 7 bacteria (Bacillus subtilis IMG 22, Pseudomonas aeruginosa DMS 50071 SCOTTA, Escherichia coli ATCC 25922, Staphylococcus aureus COWAN 1, Streptococcus mutans, Proteus vulgaris FMC 1, Salmonella typhi), yeast (Candida tropicalis ATCC 13803), and dermatofit species (Trichophyton sp.) were used in this study. Microorganisms were provided by the Microbiology Research Laboratory, Department of Biology, Faculty of Science and Arts, Firat University, Elazig-Turkey.

\section{Antimicrobial activity}

The antimicrobial tests were carried out by the disc diffusion method [29] using $100 \mu \mathrm{L}$ of suspension containing $10^{6} \mathrm{per} / \mathrm{mL}$ of bacteria, $10^{4}$ $\mathrm{per} / \mathrm{mL}$ yeast, and $10^{4} \mathrm{per} / \mathrm{mL}$ dermatofit fungi inoculated into Mueller Hinton Agar (Difco), Malt Extract Agar (Difco), and Glukoz Sabouroud Agar (Difco), respectively. The discs $(6 \mathrm{~mm})$ were then impregnated with $100 \mu \mathrm{L}$ of mushroom extract and then placed on the inoculated agar. Petri dishes were prepared at $4^{\circ} \mathrm{C}$ for $2 \mathrm{~h}$. Then, the inoculated plates were incubated at $37 \pm 0.1^{\circ} \mathrm{C}$ for $24 \mathrm{~h}$ for bacterial strains and also $25 \pm 0.1^{\circ} \mathrm{C}$ for $72 \mathrm{~h}$ for yeast and dermatofit fungi. At the end of the incubation period, the inhibition zones were measured [29]. Streptomycin sülfat (10 $\mu \mathrm{g} / \mathrm{disk})$ and Nystatin (30 $\mu \mathrm{g} /$ disk) were used as standard.

\section{Free Radical Scavenging Activity Measurement (DPPH)}

Truffle samples were extracted in $1: 5(\mathrm{~g} / \mathrm{mL})$ ratio with methanol. The free radical scavenging effect in samples was assessed by the discoloration of a methanol solution of DPPH according to the method of Brand-Williams et al. [30]. $25 \mathrm{mg} / \mathrm{L}$, $\alpha$-Diphenyl-bpicrylhydrazyl (DPPH) solution and methanol was prepared and $3.9 \mathrm{~mL}$ of this solution was mixed with $10,25,50$ and $100 \mu \mathrm{g} /$ $\mu \mathrm{L}$ concentrations of mushroom extracts. The reaction mixture was stored in darkness at room temperature for $30 \mathrm{~min}$. The absorbance of the mixture was measured spectrophotometrically at $517 \mathrm{~nm}$. The ability to scavenge DPPH free radical was calculated by the following equation: DPPH free radical scavenging activity $(\%)=\left[\left(\right.\right.$ Control $_{A B S}$ - Sample $\left.{ }_{A B S}\right) /\left(\right.$ Control $\left.\left._{A B S}\right)\right] \times 100$ where Control ${ }_{A B S}$ is the absorbance of DPPH free radical + methanol, SampleABS is the absorbance of DPPH free radical + sample extract/standard.

\section{RESULTS}

Many edible mushrooms may be used as a response to spesific health problems. As can be seen in Table 1, the extract of Terfezia and Picoa types showed activity on other test microorganisms (8-22 $\mathrm{mm})$. The antimicrobial activity of Terfezia species was observed to be very high, but observed low activity against test microorganisms as compared with Picoa species.

Table 1 shows the antimicrobial activities of the methyl alcohol extracts of truffles ( $T$. boudieri, $T$. claveryi, T. olbiensis, P. lefebvrei and P. juniperi) against certain bacteria (E. coli, B. subtilis, P. aeruginosa, S. aureus, S. mutans, $P$. vulgaris, S. typhi), yeast (C. tropicalis), and dermatofit (Trichophyton sp.) types, in terms of disc diffusion technique. It was observed that the T. boudieri, T. claveryi, T. olbiensis, $P$. lefebvrei and $P$. juniperi extracts affected the development of tested microorganisms at various levels 
(8 - $22 \mathrm{~mm}$ inhibiton zone) and were more effective than the control antibiotic (Table 1).

As seen in Table 1, the extract of $T$. boudieri inhibited the development of the test microorganisms at various rates $(10-22 \mathrm{~mm}$ diameter). The antimicrobial activity of Terfezia species was observed to be very high. The methyl alcohol extract of $T$. boudieri was $22 \mathrm{~mm}$ against S. mutans, $20 \mathrm{~mm}$ against $E$. coli, $18 \mathrm{~mm}$ against $P$. aeruginosa, $16 \mathrm{~mm}$ against $C$. tropicalis, 13 $\mathrm{mm}$ against Trichophyton sp. and $B$. subtilis, 12 $\mathrm{mm}$ against $S$. aureus, $11 \mathrm{~mm}$ against $P$. vulgaris and $10 \mathrm{~mm}$ against $S$. typhi (Table 1). The extract of $T$. claveryi was $18 \mathrm{~mm}$ against $E$. coli, $20 \mathrm{~mm}$ against $P$. aeruginosa and $S$. mutans, $15 \mathrm{~mm}$ against $B$. subtilis and Trichophyton sp., $14 \mathrm{~mm}$ against $S$. typhi, but showed low inhibition zone against the other microorganisms. The extract of $T$. olbiensis present lower activity against $S$. aureus, B. subtilis, S. mutans, P. vulgaris, S. typhi and $C$. tropicalis, but showed high activity against E. coli $(15 \mathrm{~mm})$ when compared with the control group (Table 1). The extract of $P$. lefebvrei and $P$. juniperi have a lower antimicrobial activity as to comparison antibiotic (9-14 $\mathrm{mm}$ ) (Table 1). As can be seen in Table 1, the Picoa extract showed varying degrees of antimicrobial activity against tested strains. The extract of Picoa showed low activity against $E$. coli, B. subtilis, $P$. aeruginosa, S. aureus, $P$. vulgaris, S. typhi, C. tropicalis and Trichophyton sp., but this was observed to be very high in S. mutans $(14-20 \mathrm{~mm})$ see Table 1. As a result, It was determined that methyl alcohol that was extracted from Terfezia species were more effective than Picoa species against test microorganisms (Table 1).

DPPH $(\alpha, \alpha$-Diphenyl-b-picrylhydrazyl) free radical scavenging effect could be seen at every group (Table 2), but this effect, which we evaluated in percentages, increased directly proportional with the increase in the amount of sample (Table 2). When the study groups were observed in general, it was seen that the DPPH effect was stronger at groups to which 25,50 and $100 \mu \mathrm{L}$ samples were added (Table 2 ). When the groups were compared in terms of concentration the highest level of free radical scavenging effect at the group, to which we added a $100 \mu \mathrm{L}$ sample, was seen at $T$. boudieri with $8.00 \%$ (Table 2).

\section{DISCUSSION}

Desert truffles have been used for medicinal purposes for centuries by indigenous populations. Traditional medicinal uses of desert truffles prompted modern scientific research into their bioactive properties [16-17]. Studies have shown that the skin of desert truffles is particularly rich in nutrients and bioactive compounds [17].

The in vitro antimicrobial activities of semiarid, arid or desert truffles are shown in Table 1. The antimicrobial activities of truffles are changeable as seen in Table 1 (8-22 $\mathrm{mm}$ diam.). $T$. boudieri have higher antimicrobial activity as to comparison antibiotic (9-14 $\mathrm{mm}$ ). The extract of T. boudieri showed the maximum activity against S. mutans (22 mm), E. coli (20 mm), P. aeruginosa $(18 \mathrm{~mm})$, C. tropicalis $(16 \mathrm{~mm})$, but minimum activity against $S$. aureus, $B$. subtilis, $P$. vulgaris and S. typhi see Table 1. The result of a previous study [31], methyl alcohol and ethyl acetate extract of Terfezia and Tirmania showed activity against $B$. subtilis and $S$. aureus. Methanolic extract of Terfezia truffles had antimicrobial activity against gram positive bacteria including B. subtilis and S. aureus [18]. Chloroform, acetone, methanol extracts of $T$. boudieri were observed to be more effective against bacteria and yeast (32-33). The extract of $T$. boudieri did not show any activity of $B$. megaterium, E. coli, S. aureus, C. albicans, C. glabrata, Epidermophyton spp. and Trichophyton sp., but was observed to be very high in K. pneumoniae (22). As previously discussed, indigenous populations have long used the extract of desert truffles as a remedy for eye diseases, including trachoma $[16-17,25,34]$. It seems that the antimicrobial activity of $T$. boudieri are changeable as reported by other researchers $[18,22,31-33]$. This may be indicative of the broad spectrum antibiotic compound in the truffles and due to the use of different solvent and test microorganism.

The extract of T. claveryi was observed to be very high in $S$. mutans and $P$. aeruginosa $(20 \mathrm{~mm})$, E. coli (18 mm), B. subtilis and Trichophyton sp. (15 $\mathrm{mm})$, S. typhi $(14 \mathrm{~mm})$, but lower in C. tropicalis 


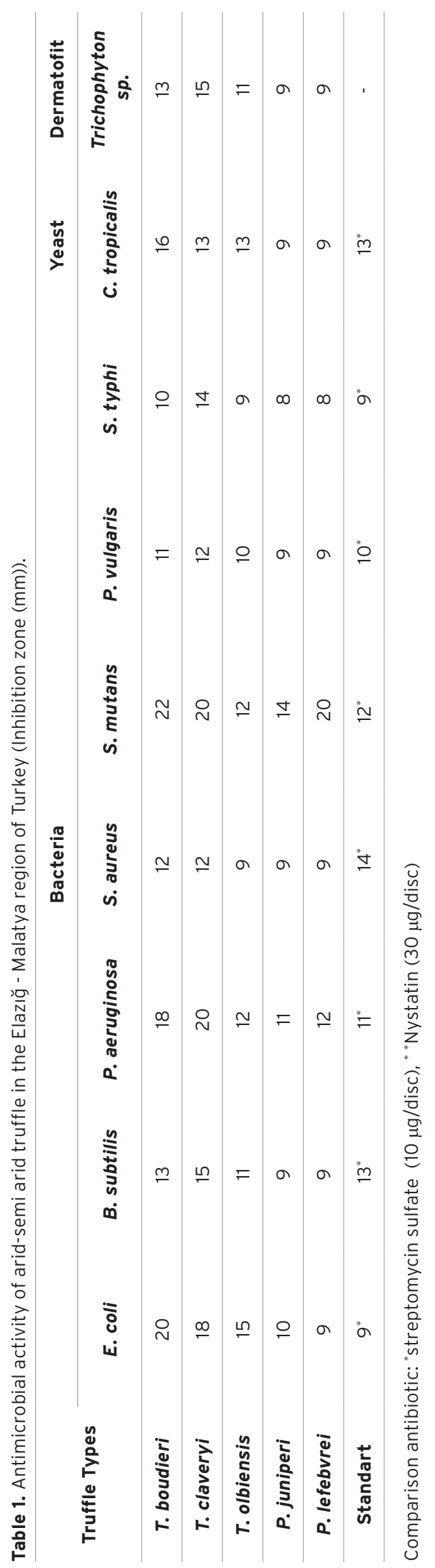

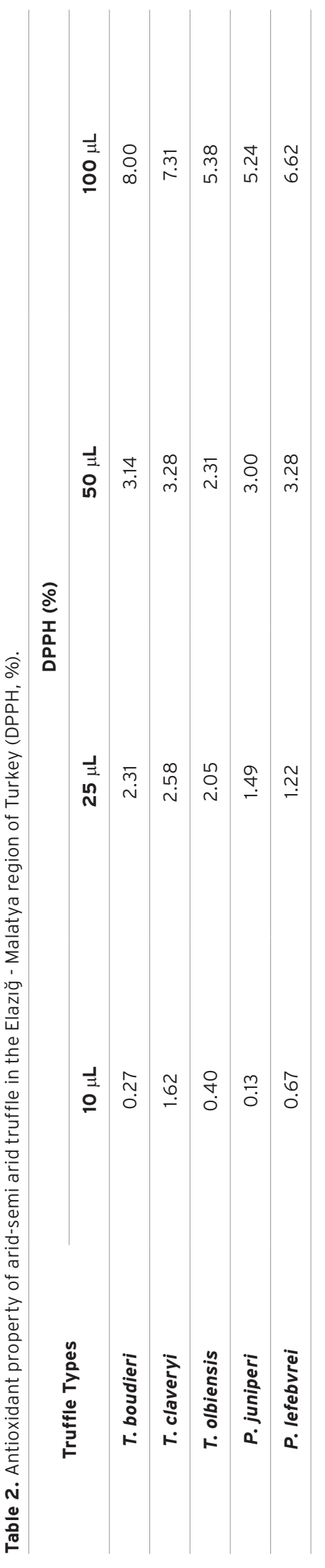


$(13 \mathrm{~mm})$ and S. aureus $(12 \mathrm{~mm})$ see Table 1 . The extract of $T$. olbiensis show lower activity against S. aureus, B. subtilis, S. mutans, P. vulgaris, $S$. typhi, C. tropicalis, but observed to be very active against $E$. coli $(15 \mathrm{~mm})$ when compared with the control group (Table 1). The juice of desert truffles, and mainly of $T$. boudieri, T. claveryi and $T$. nivea, has been used to treat eye diseases and skin lesions for centuries $[4,18,20]$. Janakat et al. [19-20] investigated the efficacy of aqueous and methanolic extracts of $T$. claveryi as well as partially purified proteins from these extracts against $S$. aureus and $P$. aeruginosa. Aldebasi et al. [35] determined the potential antibacterial activity of $T$. claveryi aqueous extract against S. aureus, S. epidermitis, S. faecalis, E. coli, P. aeruginosa, K. pneumonia, $P$. mirabilis isolates causing corneal ulcer. Bekçi et al. [36] clearly indicated that the acetone extract of $T$. claveryi have significant antimicrobial activity against B. cereus, E. coli, P. aeruginosa, S. enteritidis, S.aereus, C. glabrata ve C. albicans at different ratios. Gouzi et al. [25] evaluated aqueous extracts of $T$. claveryi, $T$. leonis, and $T$. nivea against both $S$. aureus and $P$. aeruginosa, but $T$. leonis did not show any antibacterial activity. The antimicrobial activity of $T$. claveryi and $T$. olbiensis showed activity against test microorganism are similar to those reported by several researchers [19-20,25,35-36], but some values are variable. This study indicated that there are differences in the antimicrobial effects of mushroom groups, due to phytochemical differences among species.

$P$. lefebvrei and $P$. juniperi extracts have a lower antimicrobial activity when compared to antibiotic (9-14 mm) and Terfezia species (Table 1). As can be seen in Table 1, Picoa extracts showed variying degrees of antimicrobial activity agains tested strains. Table 1 show that the extract of $P$. lefebvrei and $P$. juniperi have antibacterial and antifungal activity with a 8-20 mm zone of inhibition at the microorganisms tested, and are also observed to be very high at $\mathrm{S}$. mutans (14-20 mm), but showed low inhibition zone at other microorganisms. The antimicrobial activity of $P$. lefebvrei and $P$. juniperi showed activity against test microorganism, that are different from those reported by several researchers [18-20,22,25,31-33, 35-36], but some values were similar. They claimed that the sensivity of microorganism to chemotera- peutic compounds change even against different strains. The extracts of various mushrooms inhibited the growth of some microorganisms at different ratios. Different mushroom species posses different constituents and in different concentrations, which account for the differantial antimicrobial effects, as suggested in the reports mentioned above. The broad spectrum of antimicrobial activity may be attributed to the presence of bioactive metabolities of various chemical types in mushrooms compounds.

Antioxidant rich foods are currently valued by consumers for their positive impact on the detrimental effects of ROS induced oxidative stress which is theorised to play an important role in the development of many human degenerative diseases including inflammation, ageing, cancer and heart disease [26]. Truffles have high content of antioxidants such as vitamin $A, C, \beta$-carotene and phenolics and flavonoids compounds, besides many other bioactive compounds (anthocyanins, total esterified phenolics, total free phenolics and total flavonoids and total carotenoids etc.), which can scavenge peroxy radicals and chelate ferric ions, thus reducing lipid peroxidation etc. $[9,12,17]$. It is clearly indicated that $T$. boudieri have significant antioxidant activity against various antioxidant systems ( $\beta$-carotene/linoleic systems, reducing power, DPPH, chelating effect and superoxide anion radical scavenging effect etc. ) [37-38]. T. claveryi and P. juniperi exhibited a higher oxidative inhibition on the basis of lipid peroxidation, deoxyribose and peroxidise assays, in comparison with some common food antioxidants such as $\alpha$-tocopherol, BHA, BHT, and propyl gallate [12]. The high correlation observed between the various assays employed and phenolic content is a strong indication that these phenolics are among the predominat source of antioxidant activity in desert truffles $[9,23,38]$.

The effect to remove the DPPH radical was more efficient at groups to which samples of $25 \mu \mathrm{L}$ (1.22\% to $2.58 \%), 50 \mu \mathrm{L}$ (2.31\% to $3.28 \%$ ) and 100 $\mu \mathrm{L}(5.24 \%$ to $8.00 \%)$ were added. When the groups were compared in terms of concentration, the highest level of free radical scavenging effect at the group, to which we added a $100 \mu \mathrm{L}$ sample, was seen at $T$. boudieri with $8.00 \%$ (Table 2). It seems that the radical scanvenging activity of $T$. boudieri 
might be different than what was expressed in an earlier published report $[9,12,17,23,37-38]$. Bioactive compounds and antioxidant activity of mushrooms depend on its relation with the strain/type, the ascocarp size, harvest time, host plant, and the ecocystems. Thus, it is expected that truffles originating from different geographical origins can show some variations. Furthermore, it is also expected that the antioxidant attributes of the truffles may be affected by the nature and by the extent of association with its host root associate Helianthemum spp. as stated by Al-Laith [9]. Antioxidant activity of Terfezia and Picoa species may vary markedly among truffle species, in terms of their developmental stages, their habitats, and the analytical methods used. Our findings were supported by previous findings in the aforementioned studies.

At the end of the study, we have found that the extracts of $T$. boudieri, T. claveryi, T. olbiensis, $P$. lefebvrei and $P$. juniperi prepared with methyl alcohol revealed antimicrobial activities against some bacteria, yeasts, and dermatofit. It was observed that the biochemical components of truffles that have antimicrobial and antioxidant effects should be determined. In addition to this, it was established that different methods to determine antioxidant effects should be employed.

\section{ACKNOWLEDGMENTS}

We would like to thank TÜBITAK (The Scientific and Technical Research Council of Turkey) for supporting this project (1140065) financially.

\section{References}

1. S.P. Wasser, A.L. Weis, Medicinal properties of substances occurring in higher Basidiomycetes mushrooms: current perspectives (review), Int J Med Mush., 1 (1999) 31-62.

2. S.P. Wasser, Current findings, future trends, and unsolved problems in studies of medicinal mushrooms, Appl Microbiol Biotechnol., 890 (2011) 1323-1332.

3. S. Badalyan, Medicinal aspects of edible ectomycorrhizal mushrooms, In: A. Zambonelli, GM. Bonito (eds), Edible ectomycorrhizal mushrooms: Current knowledge and future prospects, Springer Publication, New York, (2012) 317-334.

4. E. Shavit, Truffles roasting in the evening fires. Pages from the history of desert truffles, Fungi., 1 (2008) 18-23.

5. V. Kagan-Zur, N. Roth-Bejerano, Desert truffles, Fungi., 1 (2008) 32-37.
6. V. Kagan-Zur, N. Roth-Bejerano, Y. Sitrit, A. Morte, Desert truffles: phylogeny, physiology, distribution and domestication, Springer-Verlag Berlin Heidelberg, 2014.

7. V. Kagan-Zur, Terfezias, a family of mycorrhizal edible mushrooms for arid zones. In: D. Pasternak, A. Schlissel (eds), Combating deforestation with Plants, Plenum Publishers, New York, 2001.

8. J. Diez, J.L. Manjon, F. Martin, Molecular phylogeny of the mycorrhizal desert truffles (Terfezia and Tirmania), host specificity and edaphic tolerance, Mycologia., 94 (2002) 247-259.

9. A.A.A. Al-Laith, Antioxidant components and antioxidant/antiradical activities of desert truffle (Tirmania nivea) from various Middle Eastern origins, J. Food. Comp. Anal., 23 (2010) 15-22.

10. H.A. Bokhary, A.A.A. Suleiman, MO. Basalah, S. Parvez, Chemical composition of desert truffles from Saudi Arabia, Can. Inst. Food. Sci. Tech., 20 (1987) 336-341.

11. H.A. Bokhary, A.A.A. Suleiman, M.O. Basalah, The fatty acid components of the desert truffle "Al Kamah" of Saudi Arabia, J. Food. Protec., 52 (1989) 668-669.

12. M.A. Murcia, M. Martinez-Tome, A.M. Jimenez, A.M. Vera, M. Honrubia, P. Parras Antioxidant activity of edible fungi (truffles and mushrooms): losses during industrial processing, J. Food. Protec., 65 (2002) 1614-1622.

13. M.A. Murcia, M. Martınez-Tome, A. Vera, A. Morte, A. Gutierrez, M. Honrubia, A.M. Jimenez, Effect of industrial processing on desert truffles Terfezia claveryi Chatin and Picoa juniperi Vittadini: proximate composition and fatty acids, J. Sci. Food. Agric., 83 (2003) 535-541.

14. J.M. Trappe, A.W. Claridge, D. Arora, W.A. Smit, Desert truffles of the African Kalahari: ecology, ethnomycology and taxonomy, Econ. Bot., 62 (2008) 521-529.

15. A.M. Alsheikh, J.M. Trappe, Desert truffles: The genus Tirmania, Trans. British. Mycol. Soc., 81 (1983) 83-90.

16. Q.A. Mandeel, A.A. Al-Laith, Ethnomycological aspects of the desert truffle among native Bahraini and non-Bahraini people of the Kingdom of Bahrain, J. Ethnopharmacol., 110 (2007) 118-129.

17. S. Patel, Food, health and agriculture importance of truffles: a review of current scientific literature, Curr. Trends. Biotechno.l Pharm., 6 (2012) 15-27.

18. G. Hussain, I.M. Al-Ruqaie, Occurrence in chemical composition, and nutritional value of truffles: overview, Pak J. Biol. Sci., 2 (1999) 510-514.

19. S. Janakat, S. Al-Fakhiri, A.K. Sallal, A promising peptide antibiotic from Terfezia claveryi aqueous extract against Staphylococcus aureus in vitro, Phyto. Res., 18 (2004) 810-813.

20. S. Janakat, S. Al-Fakhiri, A.K. Sallal, Evaluation of antibacterial activity of aqueous and methanolic extracts of the truffle Terfezia claveryi against Pseudomonas aeruginosa, Saudi. Med. J., 26 (2005) 952-955.

21. M. Akyuz, S. Kırbag, Antimicrobial activity of Pleurotus eryngii var. ferulae grown on various agrowastes, Eur. J. BioSci., 3 (2009) 58-63. 
22. M. Akyuz, A.N. Onganer, P. Erecevit, S. Kırbag, Antimicrobial activity of some edible mushrooms in the eastern and southeast Anatolia region of Turkey, Gazi Univ. J. Sci., 23 (2010) 125-130.

23. M. Akyüz, Nutritive value, flavonoid content and radical scavenging activity of the truffle (Terfezia boudieri Chatin), J. Soil. Sci. Plant Nutr., 13 (2013) 143151.

24. S. Janakat, M. Nassar, Hepatoprotective activity of desert truffle (Terfezia claveryi) in comparison with the effect of Nigella sativa in the rat, Pak. J. Nutr., 9 (2010) 52-56.

25. H. Gouzi, L. Belyagoubi, K.N. Abdelali, A. Khalifi, In vitro antibacterial activities of aqueous extracts from Algerian desert truffles (Terfezia and Tirmania, Ascomycetes) against Pseudomonas aeruginosa and Staphylococcus aureus, Inter. J. Med. Mush., 13 (2011) 553-558.

26. S. Wang, M.F. Marcone, The biochemical and biological properties of the world's most expensive underground edible mushroom: truffles, Food. Res. Inter., 44 (2011) 2567-2581

27. E. Shavit, E. Shavit, The medicinal value of desert truffles, In: V. Kagan-Zur, N. Roth-Bejerano, Y. Sitrit, A. Morte (Eds.), Desert truffles: phylogeny, physiology, distribution and domestication, Springer Berlin Heidelberg, pp. 323-340, (2014).

28. A. Türkoğlu, M.A. Castellano, New records of some Ascomycete truffle fungi from Turkey, Turk. J. Bot. 38 (2014) 406-416.

29. C.H. Collins, P.M. Lyne, Microbiological Methods. Butter Worths and Co Publishers Ltd., London, (1987).

30. W. Brand-Williams, M.E. Cuvelier, C. Berset, Use of a freeradical method to evaluate antioxidant activity, LWT - Food Sci. Tech., 28 (1995) 25-30.
31. A. Chellal, E. Lukasova, Evidence for antibiotics in two Algerien truffles Terfezia and Tirmania, Pharmazie, 50 (1995) 228-229.

32. S. Aydın, Terfezia boudieri Chatin ve Lactarius vellereus (Fr.) Fr.'un antioksidan, antimikrobiyal etkilerinin ve yağ asidi kompozisyonunun belirlenmesi Yüksek Lisans Tezi, Selçuk Üniversitesi Fen Bilimleri Enstitüsü, Biyoloji Anabilim Dalı, Konya, s 119. 2009.

33. H.H. Dogan, S. Aydın, Determination of antimicrobial effect, antioxidant activity and phenolic contents of desert truffles in Turkey, Afr. J. Trad. Comp. Alter. Med., 10 (2013) 52-58.

34. J.M. Trappe, A.M. Alsheikh, Desert truffles: the genus Tirmania, Trans. Br. Mycol. Soc., 81 (1983) 83-90.

35. Y.H. Aldebasi, W.G. Nouh, N.M. Abdel-Atti, M.M. Salem-Bekhit, M.A. Qureshi, S.M. Aly, Comparative pathological studies on the healing effect of natural (Terfezia claveryi) and synthetic (Vigamox) antimicrobial on corneal ulcers in rabbits, J. Pharm. Biomed. Sci., 2 (2012) 66-77.

36. H. Bekçi, B. Altınsoy, S. Sarıkaya, D. Onbaşılı, G.Y. Çelik, Antimicrobial activity of some macrofungi collected from Kastamonu province, Kastamonu Üniv. Orman Fak. Derg., 11 (2011) 187-190.

37. A. Dundar, O. Faruk, H. Acay, V. Okumus, S. Ozdemir, A. Yildiz, Antioxidant properties, chemical composition and nutritional value of Terfezia boudieri (Chatin) from Turkey, Food Sci. Tech. Inter., 18 (2012) 317-328.

38. M. Özyürek, M. Bener, K. Güçlü, R. Apak, Antioxidant/ antiradical properties of microwave-assisted extracts of three wild edible mushrooms, Food. Chem., 157 (2014) 323-331. 